\title{
Do Private Schools Manage Better?
}

\author{
Alex Bryson (UCL, NIESR, and IZA) \\ Francis Green (UCL and LLAKES) ${ }^{\dagger}$
}

\begin{abstract}
There is a perception among some commentators and policy analysts that leadership and managerial practices in private schools are superior to those in state schools. Analysing a survey of workplaces in Britain, we find little evidence to support this contention when examining the prevalence of modern human resource management (HRM) practices in schools. Rather, the evidence points to greater use of such practices in state schools. Those practices are correlated with improved school performance in the state sector, but not in the private sector. We discuss the implications of these findings for the policy of encouraging managers of private schools to sponsor state schools.
\end{abstract}

Key words: school performance; human resource management.

JEL classification: I21

Acknowledgements: Alex Bryson thanks the Nuffield Foundation (grant EDU/41926) for funding. Francis Green acknowledges support from the ESRC-funded LLAKES Centre for Research on Learning and Life Chances (grant ES/J019135/1). The authors acknowledge the Department for Business, Energy and Industrial Strategy, the Economic and Social Research Council, the Advisory, Conciliation and Arbitration Service and the National Institute of Economic and Social Research as the originators of the Workplace Employee Relations Survey data, and the Data Archive at the University of Essex as the distributor of the data. We thank seminar

\footnotetext{
† Corresponding author e-mail: francis.green@ucl.ac.uk
} 
participants at UCL and NIESR for useful comments on earlier versions of the paper. All errors and omissions remain the sole responsibility of the authors. 


\section{INTRODUCTION}

A contemporary policy response to the segmentation of private and state education in Britain is to promote strong partnerships between private and state schools, in which private schools would "sponsor" one or more state schools. It is held that social gains are available if the managerial expertise of the private schools could be shared with state schools, thereby transferring a private school ethos into the state sector. In this paper, we contribute evidence relevant to this policy discourse, by comparing managerial practices in Britain's private and state schools.

Britain's private schools are relatively unusual in an international context. They charge unusually high fees and, despite the availability of means-tested bursaries (about $4 \%$ of income), disproportionately serve families with high wealth and income. Only a small proportion -- under 7\% -- of pupils attend private schools. Apart from some relatively minor tax subsidies, the private schools receive very little government funding, and accordingly have high levels of managerial autonomy from the state - constrained only by some regulation of standards, and participation in the public external exam system (at secondary level). The high fees support a huge resource gap between the sectors, and on average private schools deliver substantial educational advantages as measured by achievements in public exams and access to high-ranking universities (Sullivan and Heath, 2003; Dearden et al., 2002; Boliver, 2013; Jerrim et al., 2015; Ndaji et al., 2016; Parsons et al., 2017). There is a corresponding earnings' gain once private school pupils have entered the labour market, and prominent positions in public and private life are found to be disproportionately dominated by those who have been privately educated (e.g. Green et al., 2011; McKnight, 2015; Green et al., 2017; Crawford et al., 2016; Green et al., 2017 online; Kirby, 2016).

While the proportion attending Britain's private schools has remained fairly constant, the schools have enjoyed a period of prosperity over recent decades. With the fees trebling in real 
terms since 1980 and increased accountability to parents, productive managerial practices such as appraisal and staff professional development, common elsewhere in industry, have been reported as emerging in private schools, displacing more traditional practices (Peel, 2015; Turner, 2015). Yet such practices have, unsurprisingly, also evolved in state schools, so it is far from clear whether there are any decisive differences between the managerial practices of the two sectors.

The idea of sponsorship in some form emerged from both sides of Britain's political spectrum. While in opposition in the 1990s, Labour party leader Tony Blair had shifted policy towards fostering a closer relationship between the private and public sectors of education, believing that the success of private schools derived in part from their strong leadership. Subsequently Andrew Adonis, Labour's Minister for Schools from 1998 to 2008 urged that successful private schools, whose "DNA" incorporated "independence, excellence innovation, social mission" should sponsor state academy schools (Adonis, 2012: 157). ${ }^{1}$ The coalition government of 2010 to 2015 envisaged a similar role for private schools in the improvement of state schools, and as of 2013 there were 36 private schools involved in some form of sponsorship of state school academies or free schools, though only five were fully involved with managerial responsibilities. Notwithstanding the diffidence with which the call for sponsorship has been heeded by most private schools, the Conservative Party's 2017 manifesto renewed the objective that private schools should be helping to improve the state sector, with the aim that at least 100 independent schools should sponsor an academy or start a free school in the state system. To give an incentive bite to the policy, England's Chief Inspector of Schools had called in 2016 for sponsorship to be linked to the retention of the

\footnotetext{
1 Speaking at the independent sector Headmasters' and Headmistresses' Conference's annual gathering in Bournemouth, Andrew Adonis said 23 private schools or foundations were now "engaged in" 47 academy projects. He told the audience: "It is your educational DNA we are seeking, not your fee income or your existing charitable endowments." BBC News, 2/10/2007. Anthony Seldon, principal until 2015 of Wellington College, one of the most prestigious private schools, has been one of the more vocal proponents of private-state sponsorship, including taking his school into a sponsorship relationship with a new local state school.
} 
financial benefits of charitable status. This negative incentive strategy was a proposed option in the manifesto, though it appeared in September 2017 to have been "rowed back on" by the new Conservative government in favour of a conciliatory, voluntarist strategy of encouragement. $^{2}$

The private and state school sectors differ markedly in terms of both resources and the composition of the student body, both of which could be expected to contribute to the private/state performance gap. Yet policy-makers are normally clear that they are not proposing resource transfers or a reallocation of students between sectors. Rather, they advocate that the ethos - typically described as involving high expectations, hard work and social mission - could be transferred through private sector managerial engagement. ${ }^{3}$ The mechanism for this transfer is, unfortunately, not made explicit, and still less is it prescribed as to exactly what practices and behaviours the private school heads should attempt to foster in the state schools that they sponsor; yet it can be expected to involve the adoption of managerial practices that might foster the required high-commitment ethos among staff and pupils alike. There is considerable variation among private schools, in terms of size, type and level of resources, and potentially also with respect to their use of good management practices - just as state schools vary also in their management capabilities. It therefore seems important to ask whether good managerial practices - as recognised in studies of organisational performance both in schools and elsewhere - are in general more prevalent in Britain's private schools than in its state schools, and hence whether fostering a private-tostate transfer of managerial expertise might be a promising scalable policy for achieving improvement in the state sector.

\footnotetext{
${ }^{2}$ https://inews.co.uk/essentials/news/education/ministers-row-back-private-school-threat/

${ }^{3}$ Though policy-makers advance this hypothesis, the schools themselves do not typically claim to have superior management expertise, even while supporting some two-way benefits of partnership. For an example of this viewpoint, see: http://www.queenswood.org/independent-and-state-schools---working-together
} 
The paper proceeds as follows. We first consider possible arguments for private/state differences in the deployment of efficient management practices in British schools, drawing both on the limited evidence from schools' analysis and the wider literature on relationships between management and organisational performance. Data and estimation methods are then presented in Section 3, our findings in Section 4, and their implications are discussed in Section 5 .

\section{POSSIBLE PRIVATE/STATE DIFFERENCES IN THE DEPLOYMENT OF EFFICIENT MANAGEMENT PRACTICES}

We draw on the now extensive literature that links variations in organisational performance, even within narrowly defined industrial sectors, with the variation in the intensity with which bundles of management practices are used (for recent examples see Syverson, 2011; Bloom et al., 2014; Bhagat and Bolton, 2008). Organisational performance is usually captured by metrics such as sales growth or profitability in the for-profit sector, or by outcomes such as increased productivity or lower closure rates more broadly. Typically, studies find that the number of structured management practices is positively associated with such outcomes. Studies vary according to the range of management practices considered: Appelbaum et al. (2000), for example, study a broad array of practices, while Bloom et al., (2017) focus more narrowly on worker monitoring, targets, and incentives. In a number of cases using quasiexperimental methods the association is shown to be causal (e.g. Bloom et al., 2017).

Other studies focus on intermediate outcomes known to relate to organisational performance, including employee job attitudes such as organisational commitment or job satisfaction. In recent literature, the positive relationship of managerial practices with attitudes is found to be 
non-linear: only when management practices are used intensively is there found to be a positive link with attitudes (White and Bryson, 2013).

Theory and evidence also suggest that the effectiveness of management practices may vary according to whether they are appropriate for the type of organisation or the market (Delery and Doty, 1996). Thus, the extent to which the findings of these studies apply in not-forprofit sectors, and in particular within education, needs to be evaluated. Runhaar (2017) makes the case that a consistent, well-designed, bundle of high-commitment HRM policies has the potential to make a large difference in schools by raising teachers' skills and commitment. In another study, Runhaar and Sanders (2016) showed that high-commitment human resource practices enhanced the relationship between knowledge-sharing and occupational efficacy. As yet evidence is relatively scarce. Yet the studies of Fryer (2014, 2017) and of Sun and Van Ryzin (2014) in the United States, of Tavares (2015) in Brazil, of Argon and Limon (2016) in Turkey, of Di Liberto et al. (2014) in Italy and of Bloom et al. (2015) across eight countries, all find indications of a positive relationship between various management practices and performance in a school setting. Related literatures have studied the importance of the quality of school leadership (e.g. Ahn and Vigdor, 2014), and the role of autonomy from government (e.g. Eyles et al., 2016) which, in one recent study is found to have a nuanced relationship with student performance in skills tests, depending on the level of a country's development (Hanushek et al., 2013). According to OECD's review of findings from many countries, "The most effective schools are led by principals who define, communicate and build consensus around the school's education goals, ensure that the curriculum and instructional practices are aligned with these goals, and foster healthy social relationships within the school community" (OECD, 2016: p.101). And OECD's analysis of PISA2015 schools and student performance data finds that educational leadership affects the association between school autonomy and performance: there is a stronger positive 
relationship between student performance in science and principals' decision-making autonomy when the principals score above the OECD average in an index of educational leadership practices. The latter is a combination of sub-indices capturing curricular leadership, instructional leadership, professional development and teachers' participation.

Whether leaders in private schools are likely to deploy efficient management practices more intensively than state school leaders is an open question. While competition theory is typically used to predict higher private sector productivity in commercial sectors, the same need not apply to non-profit sectors. The degree to which parents can choose schools is likely to be a factor. Whereas school choice has been a growing feature of state education policy in Britain since the 1980s (Ball, 2013), it is possible that more choice is available to parents opting for private education, especially where they wish to pay for boarding education in which case location is less of a limitation. Pressures from fee-paying parents, many with considerable cultural resources and high levels of education, can also bring pressure to bear on schools' policies and practices, whether through active involvement or through the threat of pupil withdrawal (Peel, 2015). To the extent that beneficial parental and competitive pressures are greater in the private sector than in the state sector, one could expect to see an evolution of more intensive effective management policies in private schools.

On the other hand, given that there are far fewer private schools than state schools, and that access is constrained by academic thresholds in many private schools, private day schools in some locations may face less competition from other private schools. And, as noted above, British private schools have enjoyed, since the early 1980s, a golden-age period of almostuninterrupted growth in their resources. Even though they have not expanded private school participation in the aggregate during this time, the rising revenues from increasing fees constitute economic quasi-rents which could be expected to have reduced the pressures on 
them to modernise their managerial practices at the same pace as developments in the state schools.

While the theoretical expectation is therefore ambiguous, the evidence on whether private schools deploy better management practices to date is limited. Bloom et al. (2015) develop an index of management practices that is correlated with student performance, covering operations, monitoring, target-setting and people management. ${ }^{4}$ The management score is found to be highest in the UK. They then investigate how the scores vary across school-types. Across a pooled sample of data from six countries, autonomous government schools exhibited significantly higher management practice scores than state funded and controlled schools; while private schools had lower management scores than either of the other school types. In India, management scores of the private schools were the highest. Finally, and most significant from our perspective, in the UK there were no significant differences between the overall management scores found in the different school types. There were, however, just 100 schools in the UK part of this study.

Here we contribute new evidence on a substantially larger sample of UK schools, and with a focus on the human resource management (HRM) practices of the schools. Our main aim is to test the hypothesis that private schools have evolved a more intensive use of efficient HRM practices (and are, in that sense, better managed). Support for policies to encourage managerial engagement by private schools in state school sponsorship and improvement should be better informed by the evidence for, or against, this hypothesis. A subsidiary aim is to investigate whether these HRM practices are positively correlated with performance measures, both in state and private schools.

\footnotetext{
${ }^{4}$ An ESRC 2014 briefing designed to inform DfE guidance for schools on better school governance draws on the findings of this research. See http://www.esrc.ac.uk/files/news-events-and-publications/evidencebriefings/improving-schools-with-better-management/
} 


\subsection{DATA}

Our data are the Workplace Employment Relations Survey (WERS) 2004 and 2011. Appropriately weighted, they are nationally representative surveys of workplaces in Britain with 5 or more employees covering all sectors of the economy except agriculture and mining (Kersley et al., 2013; van Wanrooy et al., 2013). ${ }^{5}$ Our analysis is confined to the 406 school establishments in the two surveys. The analysis exploits cross-sectional data based on management interviews, conducted face-to-face with the most senior workplace manager responsible for employee relations. All analyses are survey-weighted to account for sample selection probabilities and observable non-response biases (Van Wanrooy et al, 2013: 212-3).

Schools are identified using their five-digit Standard Industrial Classification. ${ }^{6}$ Managers are asked the formal status of the organization to which their workplace belongs, from which we distinguish public and private sector workplaces. ${ }^{7}$ We label private sector schools as private schools and public sector schools "state schools", to avoid confusion regarding the term "public school". ${ }^{8}$ Of the 406 schools in the pooled cross-sectional data 79 are private schools and 327 state schools.

Human resource management: Following White and Bryson (2013), Bloom et al. (2017) and Bryson et al. (forthcoming) we construct a single HRM index based on binary $(0,1)$ indicators

\footnotetext{
5 The TALIS survey and successive PISA surveys collect information on school principals' "leadership" (e.g. Micklewright et al., 2014). However, the sample size of private schools in these cases was very small in Britain (just 10 in the case of TALIS). These data sources were therefore unsuitable for the purposes of testing our hypotheses about private/state sector differences.

${ }^{6}$ Under the SIC 2003 classification the codes identifying schools are 80100, 80210, 80220. Under the SIC 2007 classification the relevant codes are 85100, 85200, 85310, and 85320. We are able to distinguish between primary schools (coded 80100 under SIC 2003 and 85100 or 85200 in SIC 2007); secondary schools (coded 80210 in SIC 2003 and 85310 in SIC 2007) and Technical and Vocational schools (coded 80220 in SIC 2003 and 85320 in SIC 2007).

${ }^{7}$ To avoid miscoding, converter academy schools, which have a mixed legal status but remain fully state funded, were explicitly instructed to respond in the state school category.

${ }^{8}$ In the UK many fee-paying (i.e. private) secondary schools have, through history, been termed "public schools".
} 
identifying the presence or absence of specific HRM practices. ${ }^{9}$ The 48 items available are drawn from eight HRM domains, as indicated in Appendix Table A1. These domains include five that are commonly the focus in the "high performance work systems" literature, namely teams, training, participation, selection, and incentives, together with target setting and record keeping - emphasised in the work of Bloom et al. $(2014 ; 2017)$ - and total quality management (TQM) which is often identified as key to lean production. The KuderRichardson coefficients of reliability are presented in the last column of Appendix Table A1. They range from 0.22 for the incentives indicators to 0.79 for the eleven targets.

In our empirical analysis, we investigate whether there is differential usage of HRM in private and state schools, ceteris paribus. We do so using a global measure of HRM intensity and, in alternative specifications, the eight HRM domains. In the regression analysis, because we wish to compare the quantitative size of the association with private schools across domains, each is converted into a z-score with a mean of zero and standard deviation of 1 . The composite index sums these z-scores and converts the sum into a z-score. The weighted distributions for private and state schools are presented in Figure 1.

\section{[INSERT FIGURE 1]}

Workplace performance: Ideally, studies of organisational performance make use of objective outcome indicators such as value-added or profitability where appropriate. In schools, performance is often conceived in terms of student performance in public exams, and if so that should be defined as a value-added measure. However, school outcomes could also be conceived more broadly, either in terms of the school itself, or in terms of the broader

\footnotetext{
${ }^{9}$ This is standard in the literature. As Becker and Huselid (1998: 63) say: 'The overwhelming preference in the literature has been for a unitary index that contains a set (though not always the same set) of theoretically appropriate HRM policies derived from prior work'. Although there are some small differences in the way in which some data items are coded between 2004 and 2011, it is not necessary for our measures to be identical in the two years. What is important is that we count practices in such a way as to be able to distinguish between workplaces according to their high and low intensity use of HRM within those two years.
} 
outcomes of education for the pupils often advocated by private schools. Moreover, both in schools and elsewhere such data is frequently unavailable, as here, for matching to the managerial practices data for the organisations being studied. Accordingly, recourse is made to validated indicators reported by workplace managers - measures against which organisations may appropriately be assessed in any industry.

Here we use nine metrics to capture school performance broadly. The first is a measure of workplace performance based on the HR manager's assessment on three separate measures. These measures are frequently used in the literature. For a recent example see $\mathrm{Wu}$ et al. (2015). For a discussion of these measures and their relationship with accounting measures of performance see Forth and McNabb (2008). Early studies using WERS panel data found managers' subjective assessment of poor workplace performance was predictive of subsequent workplace closure (Machin, 1995). We follow Bryson et al. (2017) in the construction of the dependent variable. It is an additive scale combining managers' responses to three questions: "Compared to other workplaces in the same industry how would you assess your workplace's...financial performance; labour productivity; quality of product or service". Responses are recorded on a 5-point Likert scale from "a lot better than average" to "a lot below average". The "a lot below average" and "below average" codes are collapsed and scales scored from 0 to 3 where $3=$ "a lot above average". Summing them gives a scale of 0 ('below average' performance on all three items) to 9 (performance 'a lot better than average' on all 3 items). The pairwise correlations between the three measures vary between 0.54 (labour productivity and product/service quality) and 0.39 (financial performance and labour productivity). Factor analysis identifies a single factor with an eigenvalue of 1.85, and an alpha reliability coefficient for the composite performance scale is 0.69 .

We also estimate the association between HRM and the three sub-components of the workplace performance scale (financial performance, labour productivity and quality of 
output/service), as well as performance as indicated by employee absence rates, quit rates, rates of injury and illness, and the climate of employment relations. These measures are further explained in the footnote to Table 3.

Controls: following Bryson et al. (forthcoming) both the HRM and workplace performance estimates account for differences in schools in terms of the number of employees in the workplace; whether the workplace is a stand-alone workplace as opposed to belonging to a multi-establishment organisation; being an older establishment aged 25 years or more; regional location; the proportion of older employees (50+) and younger (16-21 years) employees; age diversity ${ }^{10}$; the proportion female and gender diversity; the proportion from non-white ethnic minorities; the proportion part-time; the percentage union membership; the percentage in managerial posts; the percentage in professional posts; and the percentage in associate professional and technical posts.

\subsection{ESTIMATION}

To estimate the association between private schooling and HRM we estimate OLS regressions pooling the 2004 and 2011 surveys for all schools. These take the following form:

(1) hrm $_{i}=\alpha+$ Bprivate $_{i}+$ Syear $_{i}+\pi X_{i}+\varepsilon_{i}$

where hrm of workplace i denotes an HRM z-scored dependent variable, and is a function of a school's private sector status, a year dummy and, a vector of controls $X$ discussed above.

\footnotetext{
${ }^{10}$ Age diversity is calculated as one minus the sum of the squared age share terms where the age shares relate to those aged 16-21, 22-49 and 50+. The index has a minimum value of zero if there is only one category represented within the workplace and, as in our data, where we have three age categories, a maximum value of 0.67 if all categories are equally represented. Both the age share measures and age diversity measure are included in the models presented in this paper, following the practice adopted in the rest of the literature.
} 
The Greek letters are parameters to be estimated. All models are survey weighted so that results can be extrapolated to the population of workplaces with 5+ employees in Britain.

Then we estimate workplace performance equations of the following form:

$$
p_{i}=\alpha+\text { Bhrm }_{i}+\text { yprivate }_{i}+\text { Syear }_{i}+\varphi\left(\text { hrm }_{i} * \text { private }_{i}\right)+\pi X_{i}+\varepsilon_{i}
$$

where performance $p$ of workplace $\mathrm{i}$ is a function of HRM (variously defined), private school status, a year dummy, a vector of controls $X$ discussed above, with hrm* private capturing the differential returns to HRM in a private school setting. The Greek letters are parameters to be estimated. Again, all models are survey weighted so that results can be extrapolated to the population of workplaces with 5+ employees in Britain.

\section{RESULTS}

Table 1 presents the mean HRM scores for the eight HRM domains described in Section Three and the overall HRM score which sums the scores on the separate domains. Underlined numbers denote statistically significant differences between the scores for state and private schools as indicated in survey-weighted regressions containing a dummy variable denoting private schools and a year dummy.

\section{[INSERT TABLE 1]}

Whereas private schools have a mean HRM score of 24.67 out of a possible 48 HRM practices, state schools have 27.55 , a difference that is statistically significant (last row in Table 1). The difference arises because state schools use HRM more intensively in four of the eight HRM domains, namely use of team working, training, TQM, and selection of new staff. The only domain in which private schools use HRM more intensively than state schools is in 
record keeping. There are three domains (setting targets, incentives and participation) where there is no statistically significant difference. ${ }^{11}$

\section{[INSERT TABLE 2]}

These differences between state and private schools may be accounted for by traits other than the sector the school belongs to. For instance, state schools tend to be larger than private schools and, since one might expect larger schools to use more practices, it is important to account for such influences. ${ }^{12}$ Table 2 presents the differences in $\mathrm{z}$-scored HRM variables having accounted for observed differences between state and private schools. The pattern of results is similar to that presented for the raw mean differences. Private schools use significantly fewer HRM practices than observationally equivalent state schools. The effect is quite sizeable with HRM intensity in private schools being 0.38 standard deviations below that in state schools. Private schools use significantly fewer HRM practices in relation to TQM, team working, and training. The differential on selection of new staff is on the borderlines of statistical significance. However, private schools keep more records of what they do than state schools.

\section{[INSERT TABLE 3]}

We noted earlier that to avoid confusion over sector status among respondents to the survey, academy schools were explicitly instructed to identify themselves as public sector

\footnotetext{
${ }^{11}$ Results are very similar when introducing controls for secondary schools and vocational/technical schools.

12 The mean number of employees in state schools in our sample is 50, compared to 35 in private schools.
} 
workplaces. ${ }^{13}$ Nevertheless, as there could also be potential for misclassification by other types of school, we undertook further robustness checks. Firstly, we repeated these estimations after removing a small number of private establishments classified as pre-primary schools (though in practice some of these establishments may be attached to a prep school). These estimates revealed the same pattern of differences between the state and private sectors.

We also investigated the possibility that some schools may have been misclassified as a private school rather than as a state school, by checking the postcode of the establishment against other sources of information on the address, postcode and sector of schools. ${ }^{14}$ This linkage was carried out where respondents had given permission for their data to be linked to other sources of information and was conducted within the UK Data Service Secure Lab. These checks revealed no obvious misclassifications but there were a small number of schools where a match could not be identified with certainty. The same pattern of results were apparent when we removed this small number of private establishments from the analysis.

Does the differential use of HRM practices across state and private schools affect their performance? To test this proposition, we run linear regressions on the nine performance measures described in Section Three. Table 3 presents the coefficients for the private school dummy, the z-scored HRM scale and the interaction between the two. Three findings emerge. First, HRM intensity is significantly associated with higher workplace performance, as indicated by the additive scale for the subjective measures of performance, financial performance and labour productivity. It is not associated with other performance outcomes.

\footnotetext{
${ }^{13}$ Checks on the sector of schools were also undertaken as part of the editing process for the 2011 WERS.

${ }^{14}$ More specifically, for schools in England we used information available from the "Get information about schools service" (https://get-information-schools.service.gov.uk/), for schools in Wales we used the Address list of schools (http://gov.wales/statistics-and-research/address-list-of-schools/?lang=en) and for Scotland we used information from the Register of Independent Schools.
} 
Second, the positive influence of HRM intensity on workplace performance and financial performance is confined to state schools, as indicated by the negative and statistically significant interaction effects in columns 1 and 2. Third, private schools only differ from state schools on two of the nine performance measures: they have significantly higher absence rates and the rate of voluntary quits is higher in the private school sector. ${ }^{15}$

\section{DISCUSSION}

The positive associations we have found between high management scores and performance in the large majority of British schools - those in the state sector - do not establish causality in this instance, but they are consistent with earlier studies using quasi-experimental methods, both within schools and in other sectors. A question arises, however, as to why there is no observed positive association among private schools between management scores and performance. One possible interpretation is that, for some reason, better human resource management would not work among private schools. Conceivably performance is perceived and reported by managers somewhat more broadly in many private schools, taking in broader non-academic objectives that are not correlated with intensive use of proven managerial practices. Another possibility is that there is an unobserved qualitative factor in the way that the policies are being implemented, in which case an improvement in this implementation could be expected to lead to greater intensive use of strategic HRM policies in the future. A third possibility is that there is a non-linear relationship between HRM and performance in private schools, such that a positive association would emerge only when the schools become

\footnotetext{
${ }^{15}$ This is the case if one drops the interaction term, and if one removes the HRM score entirely from the regressions. Results are similar when we add controls for secondary and technical/vocational schools. Results are also similar when dropping the small number of cases where checks on the status of schools did not provide definitive evidence of their private sector status. These estimates are available from the authors on request.
} 
much more intensive in their use of strategic HRM, allowing the synergies between different elements of the policy to take effect. Such a finding could be tested with further research using a much larger private school sample, including many with intensive use of HRM practices. It could also be informative, in future research, to focus more narrowly on a measure of value-added in exam performance, treated as an indicator of organisational performance.

Our main conclusion pertains, however, to the differential use of management practices by private and state schools. There are substantive differences between Britain's private and state education sectors -- not least, there are wide disparities in resources per pupil, both in terms of pupil-teacher ratios and in the form of facilities. It is evident from research on private school choice that it is these resources, and the desirable peer groups in the socially exclusive settings of private schools, that parents are paying for (Green et al., 2018). The composition of the student body in private schools is predominantly, though not exclusively, made up of more affluent families expected to have considerable resources of cultural capital at their disposal, and with high expectations of progress from school to a good university. Yet the stated policy aim to bring about improvement in state school performance through sponsorship from (and partnership with) private schools is not expected to rest on any substantive transfer of resources from the private to the state schools. Not least, there is voiced resentment from private schools fearing a backlash from parents if many of their resources were diverted to the state sector (Paton, 2013; Wilde et al, 2016). Rather, the aspiration is that, with good management an ethos of high academic expectations can be brought to the sponsored state schools.

Yet such a policy assumes that private schools' comparative success is attributable in good part to its better management, taking advantage of the sector's high level of autonomy from government. In this paper, we have found that this assumption is not founded on any 
superiority of private schools in their use of modern, proven, observed management practices. Rather, the opposite is the case: in several domains of managerial practice, and in our overall index of good management, the private sector on average lags behind the state sector. Only with respect to record-keeping does the private sector lead. Within each sector there is considerable heterogeneity, as demonstrated in Figure 1, and there are therefore many private schools with high management scores; thus it is quite possible to conceive that a low-scoring state school would benefit from a managerial partnership with a high-scoring private school (or vice-versa). Moreover, each sector contains a range of school types, including some schools for children with special needs. Nevertheless, the evidence does not support management engagement through sponsorship (or other form of partnership) as a general policy for state sector management improvement. It remains possible, of course, that some other management practices, beyond those typically considered by management theorists, might be especially relevant in schools and not hitherto documented in sufficiently large samples of private and state schools: future research might unlock what those are. Some independent qualitative research evaluating existing sponsorship partnerships of recent years could also be useful for understanding the mechanisms of management transfer through sponsorship and where any transfers of expertise could be beneficial. 
Table 1: Mean Scores for Management Practices in State and Private Schools

\begin{tabular}{|l|l|l|}
\hline & State & Private \\
\hline Incentives $(0,4)$ & 1.93 & 1.91 \\
\hline Records $(0,9)$ & $\underline{5.99}$ & $\underline{6.89}$ \\
\hline Targets $(0,11)$ & 2.63 & 2.36 \\
\hline Teams $(0,4)$ & $\underline{2.81}$ & $\underline{2.20}$ \\
\hline Training $(0,5)$ & $\underline{3.53}$ & $\underline{2.60}$ \\
\hline TQM $(0,3)$ & $\underline{2.06}$ & $\underline{1.13}$ \\
\hline Participation $(0,5)$ & 3.22 & 2.68 \\
\hline Selection $(0,7)$ & $\underline{5.37}$ & $\underline{4.89}$ \\
\hline HRM $(0,48)$ & $\underline{27.55}$ & $\underline{\underline{24.67}}$ \\
\hline
\end{tabular}

Note: underlined figures denote statistically significant differences between the mean scores at a $95 \%$ confidence level or above as indicated in a survey-weighted regression containing a dummy for private school and a year dummy only. 
Table 2: Regression-Adjusted Incidence of z-score HRM Measures in State and Private Schools

\begin{tabular}{|l|l|l|}
\hline & Private school & Model fit $r$-squared \\
\hline Incentives & $-0.211(1.14)$ & 0.23 \\
\hline Records & $0.603(3.69)^{* *}$ & 0.28 \\
\hline Targets & $0.172(1.32)$ & 0.18 \\
\hline Teams & $-0.630(2.36)^{*}$ & 0.20 \\
\hline Training & $-0.444(2.43)^{*}$ & 0.36 \\
\hline TQM & $-0.798(4.03)^{* *}$ & 0.36 \\
\hline Participation & $-0.259(1.41)$ & 0.21 \\
\hline Selection & $-0.336(1.96)$ & 0.24 \\
\hline HRM score & $-0.381(2.51)^{*}$ & 0.36 \\
\hline
\end{tabular}

Notes: (1) Each row denotes a separate survey-weighted OLS regression. (2) Dependent variables are standardised scores for HRM domains using z-scores so that scores have a mean of zero and standard deviation of one; (3) Controls: year dummy; number of employees; single-establishment organization; region (11 dummies); workplace aged 25+ years; \% employees aged 50+; \% employees aged 16-21; age diversity; $\%$ female; gender diversity; $\%$ non-white; $\%$ part-time; $\%$ union density; $\%$ manager; $\%$ professionals; $\%$ associate professionals. (4) t-statistics in parentheses. Statistical significance: * p $<0.05 ; * *$ $\mathrm{p}<0.01$ (5) Estimation sample is 406 schools. (6) Full models are available from the authors on request. 


\begin{tabular}{|c|c|c|c|c|c|c|c|c|c|}
\hline & $\begin{array}{l}\text { Workplace } \\
\text { Performance }\end{array}$ & $\begin{array}{c}\text { Financial } \\
\text { Performance }\end{array}$ & $\begin{array}{c}\text { Labour } \\
\text { Productivity }\end{array}$ & $\begin{array}{c}\text { Quality of } \\
\text { service/output }\end{array}$ & $\begin{array}{c}\text { Log } \\
\text { absence } \\
\text { rate }\end{array}$ & $\begin{array}{c}\% \\
\text { voluntary } \\
\text { quits }\end{array}$ & Illness rate & Injury rate & $\begin{array}{l}\text { Climate } \\
\text { of } \\
\text { relations }\end{array}$ \\
\hline \multirow{2}{*}{$\begin{array}{l}\text { Private } \\
\text { school }\end{array}$} & -0.276 & -0.070 & -0.250 & -0.121 & 0.071 & 4.694 & 1.677 & 0.139 & 0.088 \\
\hline & $(0.75)$ & $(0.52)$ & $(1.30)$ & $(0.83)$ & $(2.33)^{*}$ & $(2.22)^{*}$ & $(0.73)$ & $(0.87)$ & $(0.70)$ \\
\hline HRM & $\begin{array}{l}0.621 \\
(3.18)^{* *}\end{array}$ & $\begin{array}{l}0.243 \\
(3.75)^{* *}\end{array}$ & $\begin{array}{c}0.271 \\
(3.47)^{* *}\end{array}$ & $\begin{array}{l}0.111 \\
(1.44)\end{array}$ & $\begin{array}{l}-0.057 \\
(0.96)\end{array}$ & $\begin{array}{l}-1.390 \\
(1.60)\end{array}$ & $\begin{array}{l}1.565 \\
(1.37)\end{array}$ & $\begin{array}{l}-0.016 \\
(0.21)\end{array}$ & $\begin{array}{l}-0.018 \\
(0.34)\end{array}$ \\
\hline Interaction & $\begin{array}{l}-0.966 \\
(2.97)^{* *}\end{array}$ & $\begin{array}{l}-0.289 \\
(2.70)^{* *}\end{array}$ & $\begin{array}{l}-0.218 \\
(1.33)\end{array}$ & $\begin{array}{l}-0.111 \\
(0.73)\end{array}$ & $\begin{array}{l}0.009 \\
(0.17)\end{array}$ & $\begin{array}{l}-0.471 \\
(0.21)\end{array}$ & $\begin{array}{l}-1.579 \\
(0.60)\end{array}$ & $\begin{array}{l}0.228 \\
(1.18)\end{array}$ & $\begin{array}{l}0.036 \\
(0.34)\end{array}$ \\
\hline$R^{2}$ & 0.25 & 0.26 & 0.30 & 0.21 & 0.12 & 0.41 & 0.39 & 0.10 & 0.17 \\
\hline$N$ & 335 & 370 & 341 & 385 & 319 & 384 & 406 & 406 & 400 \\
\hline \multicolumn{10}{|c|}{$\begin{array}{l}\text { Notes: (1) OLS models for private and state school performance. (2) Models pool cross-sectional data for } 2004 \text { and } 2011 \text {. (3) Dependent variables are as follows. Financial performance, } \\
\text { labour productivity and quality of service/output: ordinal scales where } 1=\text { below/a lot below average to } 4=\text { a lot better than average. Workplace performance: additive scale combining ordinal } \\
\text { responses on financial performance, labour productivity and quality of service relative to other workplaces in the industry. Scale runs from } 0 \text { (below/a lot below average on all } 3 \text { items) to } 9 \\
\text { (a lot better than average on all } 3 \text { items). The absence rate is the percentage of work days lost through sickness or absence at the workplace over the previous } 12 \text { months. The quit rate is the } \\
\text { percentage of employees who left or resigned voluntarily in last year. The illness rate is the number of employees per } 100 \text { employees who have been absent in the last } 12 \text { months due to an } \\
\text { illness caused or made worse by their work. The injury rate is the number of employees per } 100 \text { who have sustained an injury at work in the last } 12 \text { months. The climate measure is } \\
\text { managerial responses to the question "how would you rate the relationship between management and employees generally at this workplace?" with responses coded on an ordinal scale from } \\
1=\text { poor/very poor to } 4=\text { very good. (3) All models contain controls as per Table } 2 \text {. (4) t-statistics in parentheses. Statistical significance: * } *<0.05 ; * * p<0.01\end{array}$} \\
\hline
\end{tabular}


Figure 1: Distribution of overall HRM Across State and Private Schools

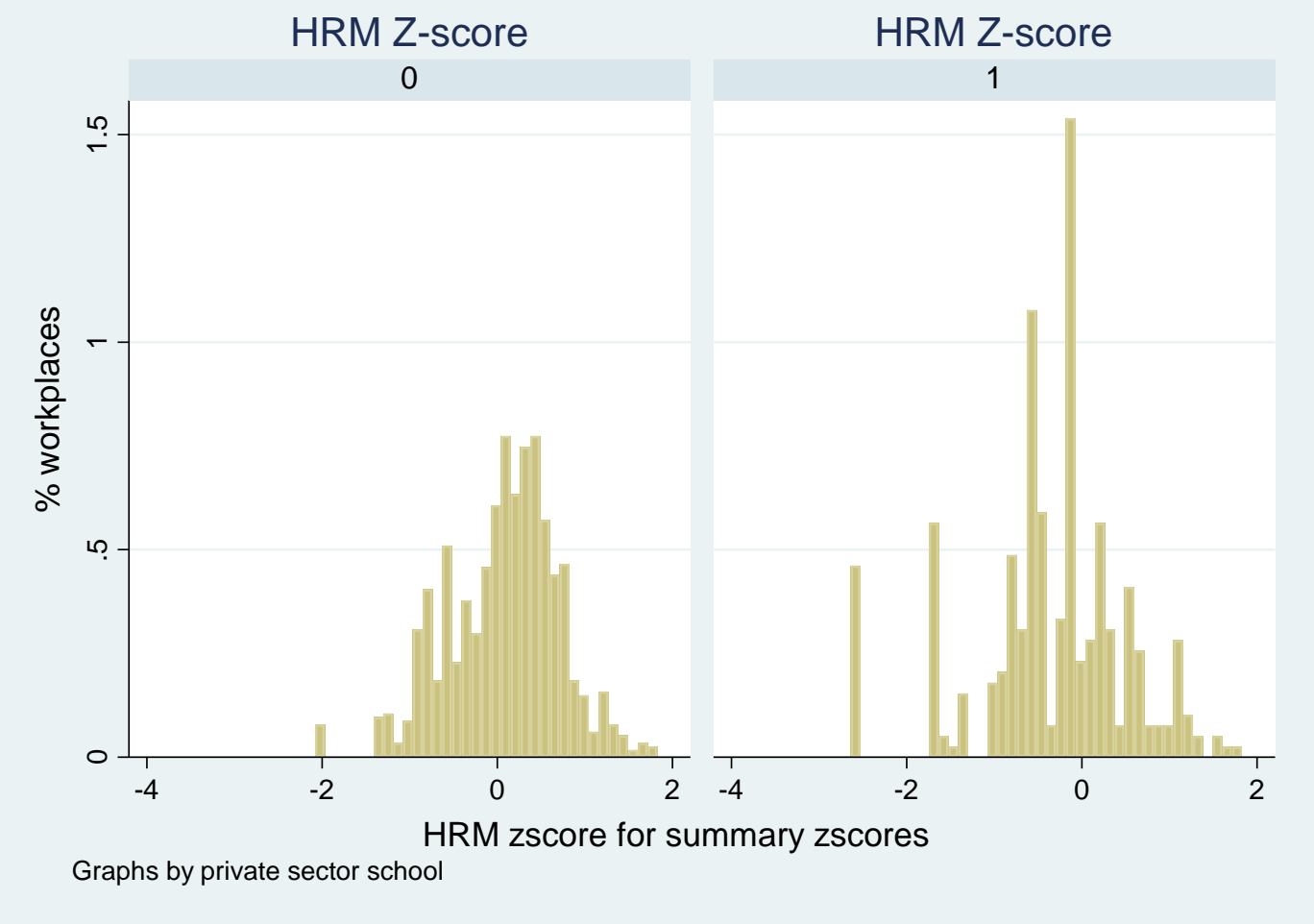




\section{References}

Adonis, A. (2012). Education, Education, Education. Reforming England's Schools. London, Biteback Publishing

Ahn, T. and Vigdor, J. (2014) "The Impact of No Child Left Behind's Accountability Sanctions on School Performance: Regression Discontinuity Evidence from North Carolina", NBER Working Paper No. 20511

Appelbaum E., Bailey T., Berg P. and Kalleberg A.L. (2000) Manufacturing Advantage: Why High-performance Work Systems Pay Off. Ithaca NY: Cornell University Press

Argon, T. and I. Limon (2016). "Strategic Human Resource Management and Organizational Innovativeness in Private Schools." 2nd International Conference on Lifelong Learning and Leadership for All (Iclel 2016): 649-655.

Ball, S. J. (2013). The Education Debate. 2nd Edition. Bristol, Policy Press.

Becker B. E. and Huselid, M.A. (1998) "High performance work systems and firm performance: A synthesis of research and managerial implications”. In Ferris GR (ed.) Research in Personnel and Human Resources Management, Vol. 16. Stamford, CT: JAI Press, 53-101.

Bhagat, S. and Bolton, B. (2008) "Corporate governance and firm performance", Journal of Corporate Finance, 13, 3: 257-273.

Bloom, N., Lemos, R., Sadun, R. and Van Reenen, J. (2015) "Does Management Matter in Schools", The Economic Journal, 125, 647-674

Bloom, N., Lemos, R., Sadun, R., Scur, D. and Van Reenen, J. (2014) "The new empirical economics of management", The Journal of the European Economic Association, 12, 4: 835-876 
Bloom, N., Brynjolfsson, E., Foster, L., Jarmin, R.S., Patnaik, M., Saporta-Eksten, I. and Van Reenen, R. (2017) “What Drives Differences in Management?”, NBER Working Paper No. 23300.

Boliver, V., 2013. How fair is access to more prestigious UK universities?. The British journal of sociology, 64(2), pp.344-364.

Bryson, A., Stokes, L. and Wilkinson, D. (forthcoming) "Can HRM Improve Schools' Performance?", UCL mimeo.

Bryson, A., Forth, J. and Stokes, L. (2017) "How Much Performance Pay is there in the Public Sector and What Are Its Effects?", Human Resource Management Journal, doi: 10.1111/1748-8583.12153.

Crawford, C., P. Gregg, L. Macmillan, A. Vignoles and G. Wynes (2016). "Higher education, career opportunities, and intergenerational inequality." Oxford Review of Economic Policy 32(4): 553-575.

Dearden, L., J. Ferri and C. Meghir (2002). "The effect of school quality on educational attainment and wages." Review of Economics and Statistics 84(1): 1-2.

Delery, J. E., and Doty, D. H. (1996) "Modes of theorizing in strategic human resource management: Tests of universalistic, contingent and configurational performance predictions", Academy of Management Journal, 39(4): 802-835

Di Liberto, A., F. Schivardi and G. Sulis (2014). Managerial Practices and Students' Performance. Bonn, IZA Discussion Paper No. 8475.

Eyles, A., C. Hupkau and S. Machin (2016). "School reforms and pupil performance." Labour Economics 41: 9-19. 
Forth, J. and McNabb, R. (2008) "Workplace performance: a comparison of subjective and objective measures in the 2004 Workplace Employment Relations Survey", Industrial Relations Journal, 39: 2, 104-123.

Fryer, R. G. (2014), “Injecting Charter School Best Practices Into Traditional Public Schools: Evidence from Field Experiments," The Quarterly Journal of Economics 129(3): 13551407.

Fryer, R. G. (2017) "Management and Student Achievement: Evidence from a Randomized Field Experiment", NBER Working Paper No. 23437.

Green, F., S. Machin, R. Murphy and Y. Zhu (2011). "The Changing Economic Advantage from Private Schools." Economica 79: 658-679.

Green, F., Henseke, G. and Vignoles, A. (2017) "Private schooling and labour market outcomes". British Educational Research Journal. 43 (1), 7-28.

Green, F., S. Parsons, A. Sullivan and R. Wiggins (2017 online). "Dreaming Big: SelfEvaluations, Aspirations, High-Valued Social Networks and the Private School Earnings Premium in the UK." Cambridge Journal of Economics.

Green, F., Anders, J., Henderson, M., \& Henseke, G. (2018). Who Chooses Private Schooling in Britain and Why? London: Centre for Research on Learning and Life Chances (LLAKES), Research Paper 62.

Hanushek, E. A., S. Link and L. Woessmann (2013). "Does school autonomy make sense everywhere? Panel estimates from PISA." Journal of Development Economics 104: 212-232.

Jerrim, J., P. D. Parker, A. K. Chmielewski and J. Anders (2016). "Private Schooling, Educational Transitions, and Early Labour Market Outcomes: Evidence from Three Anglophone Countries." European Sociological Review, 32 (2): 280-294. 
Kersley, B., Alpin, C., Forth, J., Bryson, A., Bewley, H., Dix, G. and Oxenbridge, S. (2006) Inside the Workplace: Findings from the 2004 Workplace Employment Relations Survey, Routledge, London.

Kirby (2016) "Leading People. Education Backgrounds of the UK Professional Elite", The Sutton Trust.

Machin, S. (1995) "Plant Closures and Unionisation in British Establishments", British Journal of Industrial Relations, 33:1, 55-68.

McKnight, A. 2015. "Downward mobility, opportunity hoarding and the 'glass floor'." London: Social Mobility and Child Poverty Commission

Micklewright, J., J. Jerrim, A. Vignoles, A. Jenkins, R. Allen, S. Ilie, E. Bellarbre, F. Barrera \& C. Hein (2014) "Teachers in England's Secondary Schools: Evidence from TALIS 2013". Department for Education, Research Report June 2014.

Ndaji, F., Little, J. \& Coe, R. (2016). A comparison of Academic Achievement in Independent and State Schools. Centre for Evaluation and Monitoring, Durham University.

OECD (2016). PISA 2015 Results (Volume II): Policies and Practices for Successful Schools. Paris, OECD Publishing.

Parsons, S., Green, F., Ploubidis, G.B., Sullivan, A. \& Wiggins, R.D. (2017). "The influence of private primary schooling on children's learning: Evidence from three generations of children living in the UK." British Education Research Journal, October 2017, 43(5), 823-1018.

Paton, G. (2013) “Should private schools sponsor academies?”. The Telegraph, 27/3/2013.

Peel, M. (2015). The New Meritocracy: A History of UK Independent Schools 1979-2015. London, Elliott and Thompson. 
Runhaar, P. (2017). "How can schools and teachers benefit from human resources management? Conceptualising HRM from content and process perspectives." Educational Management Administration \& Leadership 45(4): 639-656.

Runhaar, P. and K. Sanders (2016). "Promoting teachers' knowledge sharing. The fostering roles of occupational self-efficacy and Human Resources Management." Educational Management Administration \& Leadership 44(5): 794-813.

Sullivan, A., \& Heath, A. (2003). Intakes and examination results at state and private schools. In G. Walford (Ed.), British private schools: Research on policy and practice (pp. 77-104). London: Woburn Press.

Sun, R. S. and G. G. Van Ryzin (2014). "Are Performance Management Practices Associated With Better Outcomes? Empirical Evidence From New York Public Schools." American Review of Public Administration 44(3): 324-338.

Syverson, C. (2011) "What Determines Productivity?", Journal of Economic Literature, 49, 2: $326-365$

Tavares, P. A. (2015). "The impact of school management practices on educational performance: Evidence from public schools in Sao Paulo." Economics of Education Review 48: 1-15.

Turner, D. (2015). The Old Boys. The Decline and Rise of the Public School. London, Yale University Press.

Van Wanrooy, B., Bewley, H., Bryson, A., Forth, J., Freeth, S., Stokes, L. and Wood, S. (2013) Employment Relations in the Shadow of Recession: Findings from the 2011 Workplace Employment Relations Study, Palgrave MacMillan.

White, M. and Bryson, A. (2013) 'Positive Employee Attitudes: How Much Human Resource Management Do You Need?', Human Relations, 66, 3: 385-406 
Wilde, R., F. Green, P. Taylor-Gooby and S. Wiborg (2016). "Private Schools and the Provision of "Public Benefit"." Journal of Social Policy 45(2): 305-323..

Wu, N., Hoque, K., Bacon, N., Llusar, J. C. B. (2017) "High performance work systems and workplace performance in small, medium-sized and large firms", Human Resource Management Journal, 25, 4: 408-423. 


\section{Appendix Table A1: Management Practices}

\begin{tabular}{|c|c|c|}
\hline HRM Domain: & HRM measures for each domain: & KR20 \\
\hline $\begin{array}{l}\text { Incentives } \\
(0,4)\end{array}$ & $\begin{array}{l}\text { Any performance pay; managers appraised; } 100 \% \text { non-managers appraised; non-manager } \\
\text { appraisal linked to pay }\end{array}$ & 0.22 \\
\hline Records $(0,9)$ & Sales, costs, profits, labour costs, productivity, quality, turnover, absence, training & 0.71 \\
\hline Targets $(0,11)$ & $\begin{array}{l}\text { Volume, costs, profits, ULCs, productivity, quality, turnover absence, training, job sat, client } \\
\text { sat }\end{array}$ & 0.79 \\
\hline Teams $(0,4)$ & $\begin{array}{l}100 \% \text { largest non-managerial occupation in teams; teams depend on each other to perform } \\
\text { work; team responsible for products and services; team jointly decides how to do the work }\end{array}$ & 0.59 \\
\hline Training $(0,5)$ & $\begin{array}{l}80 \% \text { largest non-managerial occupation had on-job training lasts } 12 \text { months; workplace has } \\
\text { strategic plan with employee focus; Investors in People Award; standard induction programme } \\
\text { for new staff in largest non-managerial occupation; number of different types of training } \\
\text { provided is above population median. }\end{array}$ & 0.45 \\
\hline TQM $(0,3)$ & Quality circles; benchmarking; formal strategic plan for improving quality. & 0.24 \\
\hline $\begin{array}{l}\text { Participation } \\
(0,5)\end{array}$ & $\begin{array}{l}\text { Formal survey of employee views in last } 2 \text { years; management-employee consultation } \\
\text { committee; workforce meetings with time for questions; team briefings with time for questions; } \\
\text { employee involvement initiative introduced in last } 2 \text { years. }\end{array}$ & 0.38 \\
\hline Selection $(0,7)$ & $\begin{array}{l}\text { References used in recruitment; recruitment criteria include skills; recruitment criteria include } \\
\text { motivation; recruitment criteria include qualifications; recruitment criteria include experience; } \\
\text { recruitment includes personality or aptitude test; recruitment includes competence or } \\
\text { performance test. }\end{array}$ & 0.31 \\
\hline
\end{tabular}

